\title{
Diatom size plasticity at regional and global scales
}

\author{
Raquel Pinto ${ }^{1, *}$, Andreia Mortágua ${ }^{1}$, Salomé F.P. Almeida ${ }^{1}$, Sónia Serra ${ }^{2}$ and Maria João Feio ${ }^{2}$ \\ ${ }^{1}$ Department of Biology and GeoBioTec - GeoBioSciences, GeoTechnologies and GeoEngineering Research \\ Centre, University of Aveiro, Portugal. \\ 2 MARE - Marine and Environmental Sciences Centre, Faculty of Sciences and Technology, Department of Life \\ Sciences, University of Coimbra, Portugal. \\ * Corresponding author: raquel.abpn@gmail.com
}

Received: $15 / 10 / 18 \quad$ Accepted: 26/06/19

\begin{abstract}
Diatom size plasticity at regional and global scales

Studies based on diatom traits are increasing worldwide but most of them are based on database information from other geographical regions whereas data on direct observations and measurements of individuals are lacking. The aim of this study was to understand how diatom cell sizes vary at: 1) a small (regional) scale, among rivers and streams of Central Portugal with different hydromorphological and climatic characteristics (typologies) and 2) a large (global) spatial scale, comparing cell sizes from different areas of the world. For this study, species from 60 sites belonging to four Portuguese river types (Northern Mountain Streams - M; Littoral Rivers - L; Small Northern Rivers - N1 $\leq 100$ km²; Medium-Large Northern Rivers - N1 > 100 $\mathrm{km}^{2}$ ) were studied. Only species with a relative abundance of $2.5 \%$ or above were measured (length and width) and the length/width ratio was calculated, resulting in a total of 86 taxa and $\approx 3600$ specimens measured. In parallel, a revision of published information and databases on the sizes of the analysed species was done considering information from Central and Northern Europe, North and South America, Asia, Africa and Antarctica. At the regional scale, 28 of the 36 species that were present in more than one river type showed significant differences in at least one measure studied. At a global scale, in general, diatoms' lengths from Central Portugal differed from Central Europe, Northern Europe and Asia; also, diatoms' lengths from Northern Europe differed from Africa and North America. At the species level, Achnanthidium minutissimum from Portugal was different from those of Africa and Asia; Achnanthidium subatomoides and Eolimna minima were different between Central Portugal and North America and Eunotia incisa differed between Central Europe and North America. Our results produced more adjusted information on diatom sizes of Central Portugal, which differed from some of the other world regions studied. Our conclusions indicate that not considering size plasticity in diatoms' ecological studies can lead to biased results and thus further studies are needed to investigate the spatial variability of diatom traits.
\end{abstract}

Key words: diatoms, cell size, morphological traits

\section{RESUMO}

\section{Plasticidade do tamanho das diatomáceas a uma escala regional e global}

Os estudos sobre atributos de diatomáceas têm aumentado, porém, a maior parte destes dependem de dados de outras regiões geográficas havendo falta de estudos baseados em medidas e observações diretas dos indivíduos amostrados. O objetivo deste trabalho foi perceber como é que os tamanhos das diatomáceas variam: 1) numa escala espacial pequena (regional), entre rios e ribeiros da região Centro de Portugal e 2) a uma escala espacial maior (global) comparando tamanhos celulares de várias zonas do Mundo. Para isso, foram estudadas espécies encontradas em 60 locais de amostragem pertencentes a quatro tipos de rio portugueses (Rios Montanhosos do Norte - M; Rios do Litoral Centro - L; Rios do Norte de Pequena Dimensão - N1 $\leq 100$

$\mathrm{km}^{2}$; Rios do Norte de Média-Grande Dimensão - N1 > $100 \mathrm{~km}^{2}$ ). Apenas espécies com abundância relativa igual ou superior a $2.5 \%$ foram medidas (comprimento e largura) e foi calculado o rácio comprimento/largura, resultando num total de 86 taxa $e \approx 3600$ indivíduos medidos. Em paralelo, foi feito um estudo de revisão recorrendo a informação publicada e bases de dados relacionadas com o comprimento das diatomáceas do Norte e Centro da Europa, da América do Norte e do Sul, da Ásia, da África e da Antártida. À escala regional, 28 das 36 espécies analisadas mostraram diferenças significativas em pelo menos 
uma medida estudada. À escala global, em geral, os comprimentos das diatomáceas do centro de Portugal diferem dos do Centro da Europa, Norte da Europa e Ásia; assim como os comprimentos das diatomáceas do Norte da Europa diferem dos de Árica e do Norte da América. A comparação por espécie à escala global revelou que o comprimento de Achnanthidium minutissimum de Portugal foi diferente do da África e Ásia; Achnanthidium subatomoides e Eolimna minima foram diferentes entre a região Centro de Portugal e o Norte da América e o comprimento da Eunotia incisa diferiu entre a Europa Central e o Norte da América. Os nossos resultados produziram uma informação mais ajustada relativa ao tamanho das diatomáceas da região Centro de Portugal que diferiu de outras regiões mundiais incluidas neste estudo. Este trabalho indicou assim que não considerar a plasticidade do tamanho das diatomáceas em estudos ecológicos pode resultar em conclusões erróneas e, por isso, estudos futuros serão necessários para investigar a variabilidade espacial dos atributos das diatomáceas.

Palavras chave: diatomáceas, tamanho celular, atributos morfológicos

\section{INTRODUCTION}

Diatoms have been used to assess water quality for decades (e.g. Whitton \& Rott, 1996; Prygiel et al., 1999; Rey et al., 2004; Tornés et al., 2007; Tison et al., 2007; Feio et al., 2007; 2009), not only in Europe but also in other continents (Doung et al., 2007). According to the Water Framework Directive (WFD) (European Comission, 2000) diatoms are part of the biological element Aquatic Flora and therefore, obligatory for the determination of the ecological status within the European Union member states.

Autoecological indices are the most common tool for ecological assessment of rivers based on diatoms around Europe, but there are some uncertainties associated to such methods because they depend on taxonomic identification (Tapolczai et al., 2016). Uncertainties such as taxonomic misidentification, nomenclature changes and biogeographic specificity of the indices (Tapolczai et al., 2016) promoted the increase of alternative approaches that relate community traits such as life-forms, ecological guilds, biovolume and cell-size with ecological processes and factors (e.g. Rimet \& Bouchez, 2012; Algarte et al., 2014; Elias et al., 2015). In addition, trait-based approaches have the advantage of being able to relate species to the ecological functioning of the ecosystem (Statzner et al., 2001a; Feio \& Dolédec, 2012) and are well grounded on ecological theories (Statzner et al., 2001b). According to the habitat templet, traits are the result of a filtering process that selects the best-adapted species to the environment (Statzner et al., 2001b).

Cell and body-size is a trait that has been studied in different groups of organisms. Among other factors, body-size can change with temperature, precipitation, geography (e.g. Blackburn \& Hawkins, 2004; Schäuble, 2004; Ramirez et al., 2008) and environmental stress (e.g. Lange et al., 2016). There are evidences that higher temperatures and low precipitation favour smaller specimens in a variety of groups such as insects (e.g. Roberston, 1959; Atkinson, 1994; Stillwell \& Fox, 2009), amphibians (e.g. Bizer, 1978; Brady \& Griffiths, 2000; Denver et al., 1998; Schäuble, 2004), marine invertebrates (e.g. Williamson et al., 2002; Daufresne et al., 2009; Irie \& Fisher, 2009), fish (e.g. Sahin, 2001; Desai \& Sing, 2009), mammals (Boyce, 1978) and plants (e.g. Kim, 2007; Hovenden, 2008; Ledesma et al., 2008).

In the case of diatoms, species display a large range of cell-sizes (Round et al., 1990) and cell-size also varies over the life cycle. In pennate diatoms, reproduction is primarily asexual, as cells divide in two similar daughter cells, in which one of them is slightly shorter than the other one, whereas width and depth change relatively less causing a reduction in average cell-size of the population (Round et al., 1990; Mann et al., 1999). Sexual reproduction produces auxospores by gamete fusion reestablishing the original size of the species (Amato et al., 2005).

Explaining the relationship between diatom cell sizes and environmental conditions has been a challenge for diatomists. Some studies showed that there isn't a clear correlation between diatom cell size and organic pollution and nutrients (Lavoie et al., 2006; 2010; Berthon et al., 2011) whereas other studies found a correlation (Carrick \& Lowe, 1989; Morin et al., 2001; Lange et al., 2016). For example, Lange et al. (2016) showed that a low concentration of nutrients 
favours smaller taxa, which can be related to their higher surface to volume ratios, that confer them a higher capacity for nutrient uptake (Litchman et al., 2006; Reynolds et al., 2006). Simultaneously, they have lower sinking rates, which is an advantage in water stratification that often happens in lakes (Winder \& Sommer, 2011). Other examples of conditions that have been linked with diatom cell size are conductivity (Neustupa et al., 2013), and streamflow (Lange et al., 2016) and grazing (Tall et al., 2006). Previous studies relating temperature with diatom size show contradictory conclusions: some scientists suggest that primary producers are smaller in higher temperatures following the same patterns as other species (e.g. Li et al., 2009; Winder et al., 2009; Moran et al., 2010; Lewandowska \& Sommer, 2010) probably because warmer water has less capacity to hold nutrients and oxygen (Sheridan \& Bickford, 2009) and as said before smaller diatoms have a higher capacity for nutrient uptake (Litchman et al., 2006; Reynolds et al., 2006); other scientists proved that diatoms are a very important exception to the general rule (Adams et al., 2013).

Despite the increasing number of trait-based diatom studies, most of them are based on database information that might be from other geographical regions whereas data on direct measurements is lacking. Thus, the aim of this study was to check if diatom sizes differ at the regional and global spatial scales. For that, we compared diatom community and species sizes from different river types in the Central Portuguese region (regional spatial scale) and among regions around the world (global spatial scale).

\section{MATERIALS AND METHODS}

\section{Study sites}

Diatoms measured in this study were collected in the spring of 2017 in 60 sites located in the central region of Portugal and belonging to different river types (Northern Mountain Streams - M;
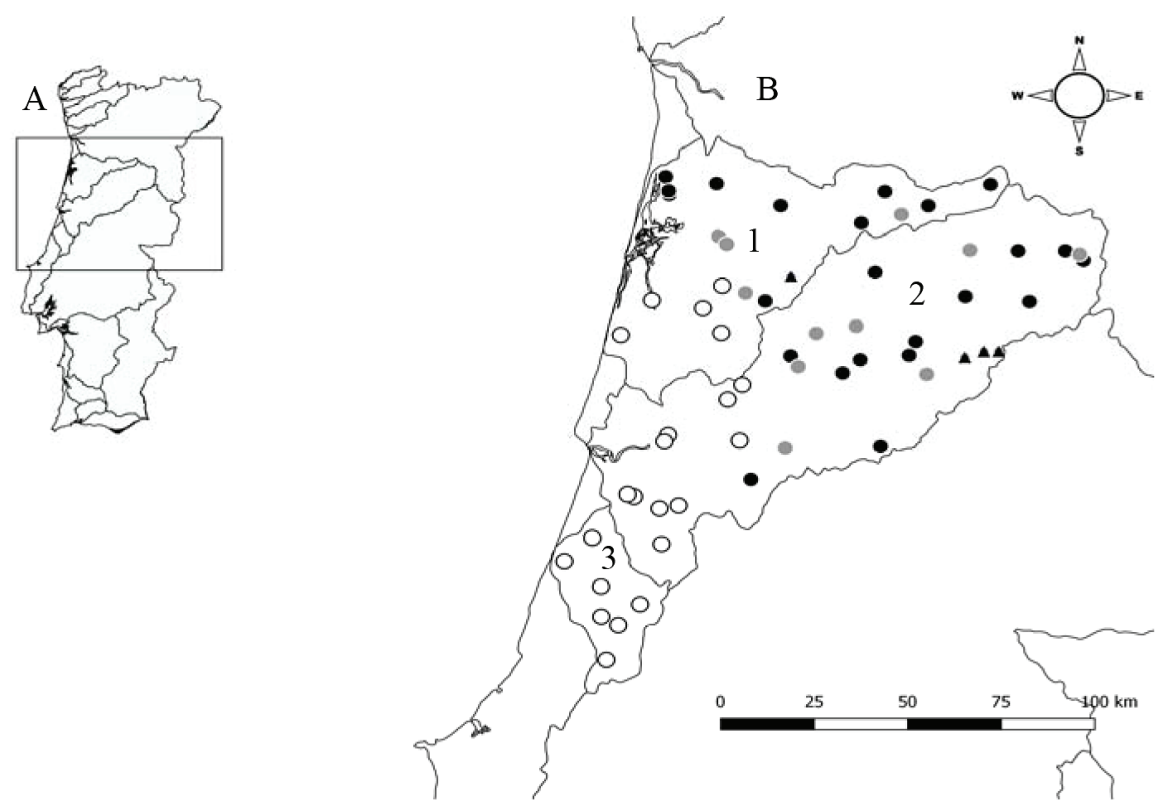

Figure 1. Map of the study sites in the central region of Portugal. A) Continental Portugal. B) Location of sampling sites according to typology: ○ - Littoral Rivers; - - Large Northern Rivers; • - Small Northern Rivers; $\boldsymbol{\Delta}$ - Northern Mountain Streams. 1- Vouga Basin, 2 - Mondego Basin, 3 - Lis Basin. Mapa dos locais de amostragem da região centro de Portugal. A) Portugal Continental. B) Localização dos locais de amostragem de acordo com a tipologia: o - Rios do Litoral Centro; • - Rios do Norte de Média-Grande Dimensão; • - Rios do Norte de Pequena Dimensão; $\mathbf{\Delta}$ - Rios Montanhosos do Norte. 1 - Bacia Hidrográfica do Vouga, 2 Bacia Hidrográfica do Mondego; 3 - Bacia Hidrográfica do Lis. 
littoral rivers - L; small northern rivers - N1 $\leq 100$ $\mathrm{km}^{2}$; medium-large northern rivers - N1 $>100$ $\mathrm{km}^{2}$ ), as represented in figure 1 .

All the river types are characterized by low mean annual temperature $\left(11-13{ }^{\circ} \mathrm{C}\right)$ and high mean annual precipitation (1200-1900 $\mathrm{mm}$ per year), except for the Littoral Rivers, which have higher mean annual temperature $\left(15^{\circ} \mathrm{C}\right)$ and lower mean annual precipitation $(900 \mathrm{~mm}$ per year) (INAG, 2008a). The highest altitudes are registered in Northern Mountain Streams (506.02 $\pm 299.75 \mathrm{~m}$ ), which differ the most from Littoral Rivers $(40 \mathrm{~m})$; in Small and Medium-Large Northern Streams altitude ranges between 200 and $600 \mathrm{~m}$. The river types also differed in other aspects such as catchment area dimension and flow regime: the Northern Mountain Streams have the lowest mean catchment area $\left(\approx 25 \mathrm{~km}^{2}\right)$ and the highest flow regime (600 to $2200 \mathrm{~mm}$ ); the catchment area of Small Northern Streams is approximately $33 \mathrm{~km}^{2}$ and the flow regime is 100 to $1800 \mathrm{~mm}$; Littoral Rivers have a catchment area of approximately $180 \mathrm{~km}^{2}$ and the lowest flow regime (50-1000 $\mathrm{mm}$ ) and the medium-large northern rivers have a catchment area of approximately $549 \mathrm{~km}^{2}$ and a flow regime of $100-2200$ $\mathrm{mm}$. Precipitation coefficient and air temperature do not differ much in the river types studied and assume values of approximately 0.30 and $10{ }^{\circ} \mathrm{C}$ respectively (INAG, 2008a; Feio \& Pinto, 2009).

Air temperatures registered during the year of 2017 were extremely high (IPMA, 2017) so the mean annual temperature for the sampling sites were higher than expected $\left(19.16-19.41{ }^{\circ} \mathrm{C}\right)$ (Accuweather, 2018).

\section{Sample collection and processing}

Sampling of biofilms and treatment of diatoms was performed according to European standards (European Committee of Standardization, 2003; 2004; 2006). In each site, the diatoms were collected from hard substrate (rocks or stones). The epilithic biofilm was collected from random submerged stones. The upper surface (approximately $100 \mathrm{~cm}^{2}$ ) was scraped with a toothbrush. The samples were preserved with formalin $(8 \%$ final volume). To ensure that the diatoms were predominantly alive when sampled, an observa- tion of the preserved samples was performed under the light microscope. The samples were then oxidized using concentrated nitric acid and potassium dichromate for 24h (INAG, 2008b). Permanent slides were mounted using Naphrax ${ }^{\circledR}$ (Brunel Microscopes Ltd., UK). Identification of diatoms mainly using the floras of Krammer and Lange-Bertalot (1986; 1988; 1991a; 1991b) and Krammer (2000; 2001; 2002; 2009) followed by enumeration of about 400 valves (AFNOR, 2000) from each slide was performed under the light microscope (Leitz Biomed 19) (100x objective and 1.32 numerical aperture).

In each sampling site, water temperature $\left({ }^{\circ} \mathrm{C}\right)$, conductivity $(\mu \mathrm{S}), \mathrm{pH}$ and dissolved $\mathrm{O}_{2}$ were measured with a multiparametric meter (WTW Multi 3430 SET F) and the habitat quality assessment score (HQA score) which translates the diversity of habitats found in the river channel, followed the Habitat River Protocol (Raven et al., 2002).

\section{Measurement of individuals}

From each sample, 10 valves from each of the diatom species with abundance of $2.5 \%$ or above were photographed with an Olympus DP70 digital camera installed in the light microscope Zeiss Axioplan 2 Imaging (100x objective and 1.40 numerical aperture). This resulted in about 3600 micrographs from 86 taxa because some taxa were present in more than one sample. Using the images and the respective scales, the length and width were measured and the ratio length/width was calculated.

\section{Abiotic characterization of the sampling sites}

To understand which of the abiotic factors considered (water temperature, conductivity, $\mathrm{pH}$, dissolved $\mathrm{O}_{2}$ and HQA score) contributed the most for the separation of the sampling sites according to river typology, a Principal Component Analysis (PCA) was performed using PRIMER 6 (Clarke \& Gorley, 2006).

\section{Diatom size plasticity at a regional scale}

Differences between diatom lengths, widths and ratios among the four Portuguese river types from the central region of the country were tested using 


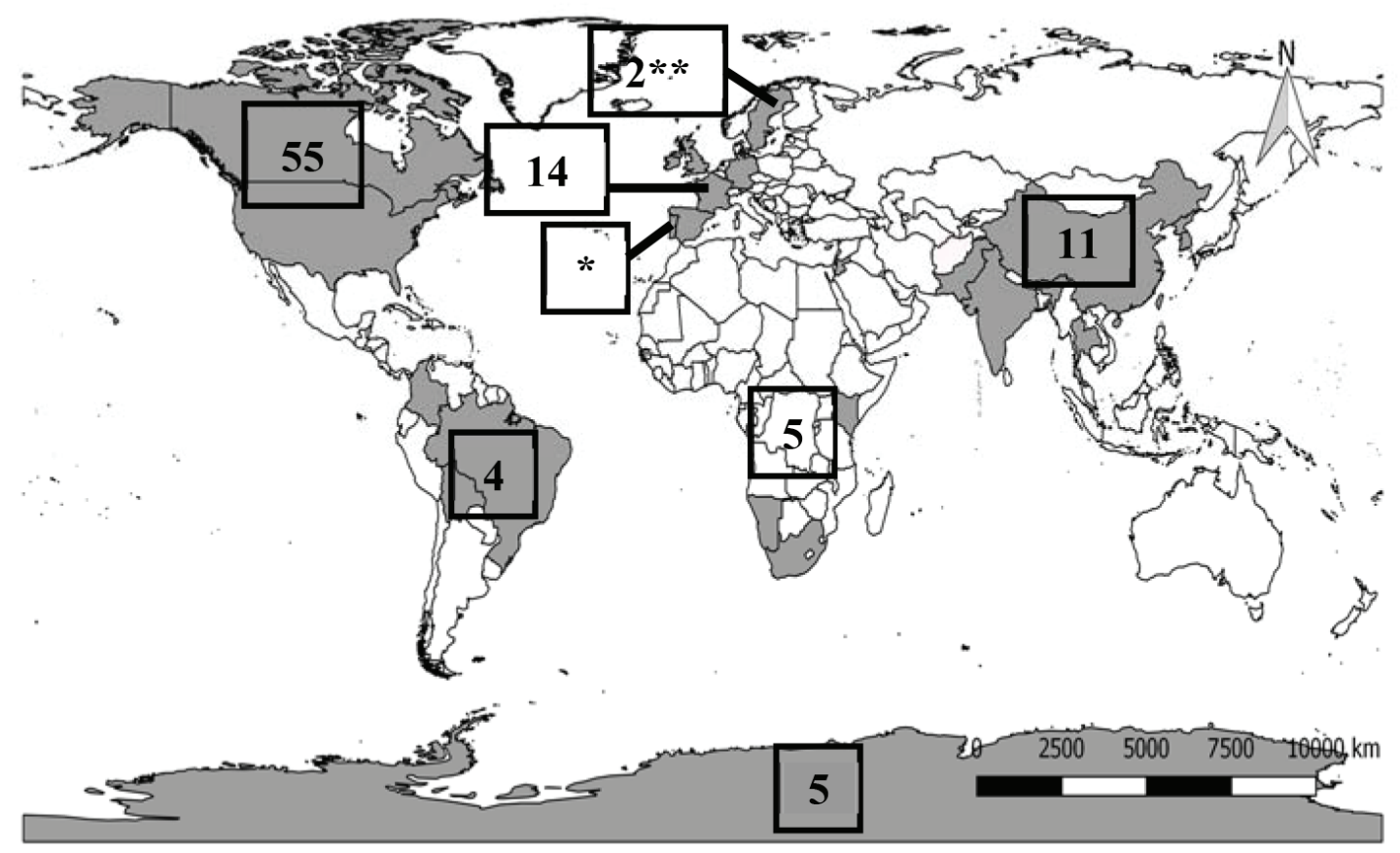

Figure 2. World map showing the regions used to analyse diatom sizes (grey). The numbers in a square represent the number of references used in each geographic region. * - our results; ** - based on a database and a flora. Mapa-mundo representativo das regiões usadas para analisar as diferenças de tamanho das diatomáceas entre regiões geográficas (cinzento). Os números representam o número de referências usadas para cada região geográfica. * os nossos resultados, ** - baseado numa base de dados e numa flora.

PERMANOVA [PRIMER 6, Clarke \& Gorley (2006) with the add-on PERMANOVA+ for Windows, Anderson et al. (2008)]. In the first analysis, all the species were considered together and then the tests were carried out for each of the species present in more than one river type.

Preliminarily to all the analyses, a PERMDISP was done to test the homogeneity of the variances. When the assumption was not verified the data was transformed in order to achieve the homogeneity of variances.

\section{Diatom size plasticity at a global scale}

To investigate diatom size plasticity around the world, a revision of published information took place (see references in supplementary information available at: http://www.limnetica.net/en/ limnetica) which included: diatom floras, scientific papers, and on-line databases from Northern and Central Europe, North America, South America, Asia, Africa and Antarctica. The countries

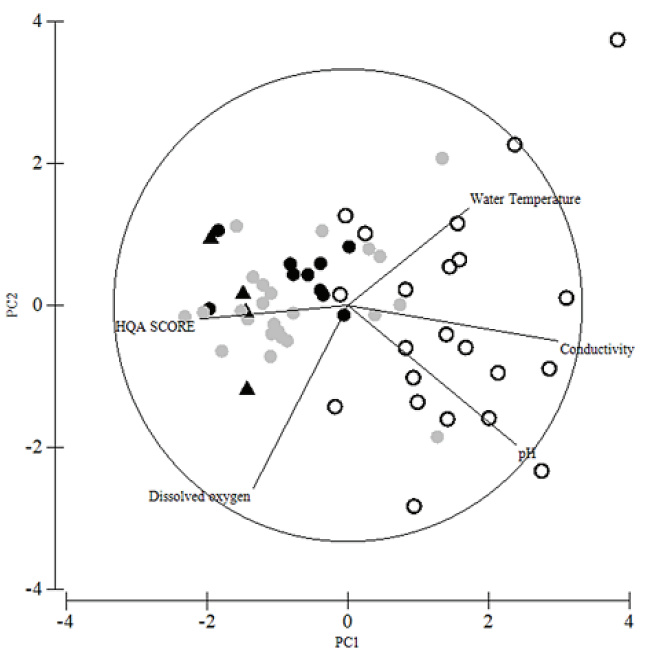

Figure 3. Principal Component Analysis (PCA) showing the abiotic characterization of the sampling sites. $\bigcirc-$ L: Littoral Rivers; - - N1MM: Medium-Large Northern Rivers; - - N1m: Small Northern Rivers; $\boldsymbol{\Delta}$ - M: Small Mountain Streams. Análise de Componentes Principais (PCA) para caracterização abiótica dos locais de amostragem. $\bigcirc-$ L: Rios do Litoral Centro; $\bullet-N 1 M M$ : Rios do Norte de Média-Grande Dimensão; - N1m: Rios do Norte de Pequena Dimensão; $\mathbf{\Delta}$ - M: Rios Montanhosos do Norte. 
included in the analysed regions are represented in figure 2 in grey. The comparison of diatom sizes found in each global region was based on the maximum and minimum values found in literature ((maximum length + minimum length)/2) and performed using Permutational Multivariate Analysis of Variance, PERMANOVA (software PRIMER 6, Clarke \& Gorley, 2006; add-on PERMANOVA+ for Windows, Anderson et al., 2008). Only species represented in at least 2 regions and with at least 2 values per region (including Portugal) were considered in this analysis. For Central Portugal, an average of each river type measurements was used. This analysis was performed considering all the species together and comparing per species.

PERMDISP analysis was also performed to test the homogeneity of variances before the size comparisons at a global scale.

\section{RESULTS}

\section{Abiotic characterization of the sampling sites}

The PCA in figure 3 showed differences between the four river types based on the parameters

Table 1. Comparison of the length of common diatom taxa in more than 1 river type of central Portugal (Northern Mountain Streams - M; Littoral Rivers - L; Small Northern Rivers - N1 $\leq 100 \mathrm{~km}^{2}$; Medium- Large Northern Rivers - N1 > $100 \mathrm{~km}^{2}$ ) that showed at least one significant difference. Pseudo-F values for PERMANOVA pairwise test results in which $0.05 \geq p \geq 0.01$ are represented with * and results in which $p \leq 0.01$ are represented with **. Analysis in which variances are not homogeneous are represented with a Comparação do comprimento dos taxa de diatomáceas comuns em mais que 1 tipo de rio da região centro de Portugal (rios Montanhosos do Norte - M; Rios do Litoral Centro - L; Rios do Norte de Pequena Dimensão - N1 $\leq 100 \mathrm{~km}^{2}$; Rios do Norte de Média Grande Dimen$s \tilde{a} o-N 1>100 \mathrm{~km}^{2}$ ) que demonstraram pelo menos uma diferença significativa. Valores Pseudo-F dos testes PERMANOVA nos quais $0.05 \geq \mathrm{p} \geq 0.01$ estão representados com *e os resultados nos quais $\mathrm{p} \leq 0.01$ estão representados com **. As análises em que as variâncias não são homogéneas estão representadas com $a$.

\begin{tabular}{|c|c|c|c|c|c|c|}
\hline Taxa & $\mathbf{L} \neq \mathbf{M}$ & $\mathrm{L} \neq \mathrm{N} 1 \leq 100 \mathrm{~km}^{2}$ & $\mathrm{~L} \neq \mathrm{N} 1>100 \mathrm{~km}^{2}$ & $\mathrm{M} \neq \mathrm{N} 1 \leq 100 \mathrm{~km}^{2}$ & $\mathrm{M} \neq \mathrm{N} 1>100 \mathrm{~km}^{2}$ & $\mathrm{~N} 1 \leq 100 \mathrm{~km}^{2} \neq \mathrm{N} 1>100 \mathrm{~km}^{2}$ \\
\hline $\begin{array}{l}\text { Achnanthidium } \\
\text { minutissimum }\end{array}$ & $2.19^{*}$ & 0.5 & 0.75 & $2.11 *$ & 1.29 & 1.03 \\
\hline $\begin{array}{l}\text { Achnanthidium } \\
\text { straubianum }\end{array}$ & & 0.76 & $7.85 * *$ & & & $6.13 * *$ \\
\hline $\begin{array}{l}\text { Achnanthidium } \\
\text { subatomoides }\end{array}$ & 0.22 & 0.24 & 1.46 & 0.63 & $2.56 *$ & 0.94 \\
\hline $\begin{array}{l}\text { Achnanthidium } \\
\text { subhudsonis }^{a}\end{array}$ & & & & & & $2.28 *$ \\
\hline Amphora inariensis & & $3.02 * *$ & & & & \\
\hline $\begin{array}{l}\text { Cocconeis placentula } \\
\text { var. lineata }\end{array}$ & & $3.55 * *$ & $2.70^{*}$ & & & 0,57 \\
\hline Eolimna minima & $3.52 * *$ & $9.20 \mathrm{E}-02$ & 0.12 & $3.75 * *$ & $4.16^{* *}$ & 0.24 \\
\hline Fragilaria parva & & & $3.84 * *$ & & & \\
\hline $\begin{array}{l}\text { Gomphonema } \\
\text { parvulum }\end{array}$ & 0.19 & $2.12 *$ & $2.06^{*}$ & $2.42 *$ & $2.44 *$ & 0.67 \\
\hline $\begin{array}{l}\text { Gomphonema } \\
\text { rhombicum }\end{array}$ & & & & $2.8475^{* *}$ & $4.1244 * *$ & 11.054 \\
\hline $\begin{array}{l}\text { Gomphonema } \\
\text { uniserhombicum }\end{array}$ & & & & & $4.39 * *$ & \\
\hline Karayevia oblongella & $4.22 * *$ & 1.55 & 0.79 & $5.90 * *$ & $7.37 * *$ & 0.32 \\
\hline $\begin{array}{l}\text { Navicula } \\
\text { cryptotenella }\end{array}$ & & & $6.80 * *$ & & & \\
\hline $\begin{array}{l}\text { Navicula } \\
\text { cryptotenelloides }\end{array}$ & & $15.12^{* *}$ & & & & \\
\hline Nitzschia dissipata & & 1.16 & $3.73 * *$ & & & 1.35 \\
\hline $\begin{array}{l}\text { Nitzschia palea var. } \\
\text { debilis }\end{array}$ & & $2.52 * *$ & & & & \\
\hline Surirella brebissonii & & $5.57 * *$ & & & & \\
\hline $\begin{array}{l}\text { Sellaphora } \\
\text { seminulum }\end{array}$ & & $2.26^{*}$ & 0.31 & & & $2.01 *$ \\
\hline
\end{tabular}


analysed. The littoral rivers are segregated from the other three river types due to higher water temperature, conductivity and $\mathrm{pH}$ and to a lower HQA score. These variations were largely explained by the first axis (PC1-43\%); while small northern rivers and northern mountain rivers showed larger HQA score and oxygenation than medium-large rivers.

\section{Diatom size plasticity at a regional scale}

The mean lengths, widths and length/width ratios measured in this study per species and the micrographs of the common species in the four river types included in this study are represented in the supplementary information (available at: http:// www.limnetica.net/en/limnetica). The majority of the species ( 28 of the 36 species measured in more than one river type) showed significant differences between river types for at least one of the measurements $(p<0.05)$. Tables 1,2 and 3 represent the taxa with significant differences in length, width and ratio, respectively.

Yet, each species varied differently when comparing length, width and ratio between the four river types studied (see in figure 4 the example of Achnanthidium and Gomphonema species, two widespread genera).

Despite the absence of patterns in diatom size plasticity at the regional spatial scale, in this
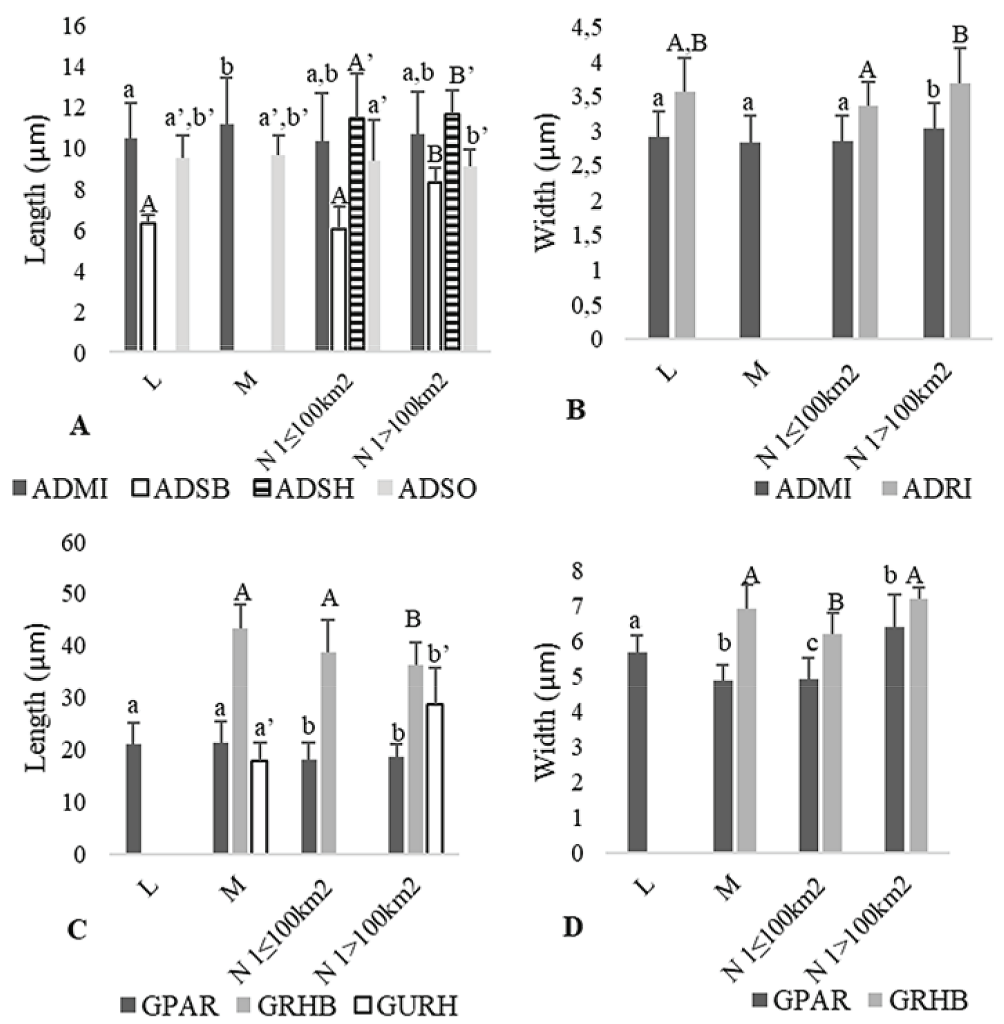

Figure 4. Comparison of mean lengths (A, C) and widths (B, D) of Achnanthidium (A, B) and Gomphonema (C, D) species that showed at least one significant difference between river types. Different letters of the same type represent significant differences in terms of length and width $(p<0.05)$, each type of letter is associated with the same species. ADMI - Achnanthidium minutissimum; ADRI - Achnanthidium rivulare; ADSH - Achnanthidium subhudsonis; ADSO - Achnanthidium subatomoides; GPAR - Gomphonema parvulum; GRHB - Gomphonema rhombicum, GURH - Gomphonema uniserhombicum. Comparação dos comprimentos (A, $C)$ e larguras $(B, D)$ médias das espécies pertencentes aos géneros Achnanthidium $(A, B)$ e Gomphonema $(C, D)$ que demonstraram pelo menos uma diferença significativa entre tipos de rio. Diferentes letras dentro do mesmo tipo representam diferenças significativas em termos de comprimento e largura ( $\mathrm{p}<0.05)$, cada tipo de letra está associado a uma espécie diferente. 


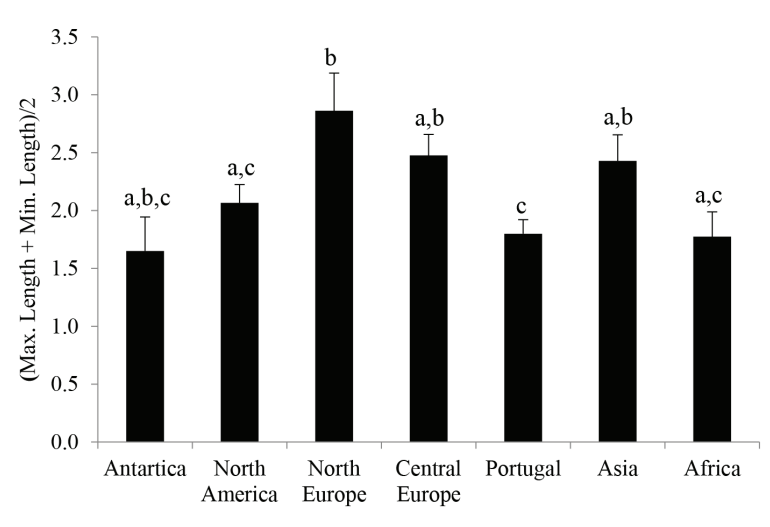

Figure 5. Comparison of the values (Maximum lengths + Minimum lengths) $/ 2$ considering the species from different geographic areas around the world. Different letters represent regions with significant differences in terms of diatom size $(p<$ 0.05). Comparação dos valores (Comprimento Máximo + Comprimento mínimo)/2 considerando as espécies todas a nivel mundial, letras diferentes representam pares de regiões com diferenças significativas em termos de tamanho das diatomáceas $(\mathrm{p}<0.05)$.

study, lengths and ratios of the species belonging to the genus Amphora (Amphora pediculus and $A$. inariensis) tended to be larger in Littoral Rivers than in Small Northern Rivers.

\section{Diatom size plasticity at a global scale}

Considering all the species together, there were significant differences between some geographic regions (Fig. 5): diatoms in Portugal were significantly smaller when compared with Asia $(\mathrm{t}=$ 2.3758; $p=0.021$ ) and the other areas of Europe studied - Central Europe $(\mathrm{t}=3.2132 ; p=0.004)$ and Northern Europe $(\mathrm{t}=3.1548 ; p=0.005)$. Diatom mean lengths in Northern Europe were significantly larger than in North America $(\mathrm{t}=$ 2.1819; $p=0.024)$ and Africa $(\mathrm{t}=2.696 ; p=$ 0.015). South America was excluded from this analysis because the data covered a small number of species.

Per species size comparison revealed that Achnanthidium minutissimum, Achnanthidium subatomoides, Eolimna minima and Eunotia incisa showed significant differences in some geographic regions (Fig. 6): lengths of Achnanthidium minutissimum from Central Portugal were significantly smaller than those from Africa $(\mathrm{t}=2.8708 ; p=$
$0.021)$ and Asia $(\mathrm{t}=3.0483 ; p=0.019)$; lengths of Achnanthidium subatomoides in Central Portugal were significantly larger than those registered in North America $(\mathrm{t}=3.0952 ; p=0.03)$; lengths of Eolimna minima from Central Portugal were smaller than those from North America $(\mathrm{t}=2.839$; $p=0.026)$ and the lengths of Eunotia incisa from Central Europe were larger than those from North America $(\mathrm{t}=3.4478 ; p=0.03)$.

The (maximum length + minimum length) $/ 2$ values collected for each region are represented in the supplementary information with the respective references.

\section{DISCUSSION}

The comparative study of diatom cell size at the regional and global scales revealed that this biological trait varies at both scales considered. Previous studies also showed the size variation of diatom species. A study based on the diameter of two Rhizosolenia species revealed that larger specimens occur in sites with lower temperatures (Wimpenny, 1936). Also, in a more recent study it was shown that the diatom Brachysira vitrea decreased size in metal contaminated sites (Luis et al., 2011). Yet, this is the first study analysing this issue with a large number of samples and at the global scale.

Size variations at species level have also been recorded for other aquatic and terrestrial organisms. For example, in anurans it is known that low temperatures may influence growth and development rates in larval and juvenile stages which have follow-on effects on maturity and growth and consequently high latitude and altitude individuals should be generally larger than the low latitude and tropical specimens (Berven, 1982, Zhong et al., 2018). Lower temperatures trigger a similar effect in marine invertebrates (Irie \& Fisher, 2009; Daufresne et al., 2009), fish (Desai \& Singh, 2009; Sahin, 2009), arthropods (Stillwell \& Fox, 2009; Brehm et al., 2018) and other amphibians (Bizer, 1978; Schäuble, 2004).

Considering the Portuguese river types analysed we found significant differences in about $78 \%$ of the species. Yet in most cases, no general trends were identified in size plasticity at 
this spatial scale: some species were larger in a certain river type while other taxa were smaller for that same river type, in spite of the differences in parameters such as water temperature, conduc- tivity and $\mathrm{pH}$ among river types. Different conclusions were drawn in other studies where it was demonstrated that diatom cell size may respond to conductivity (Neustupa et al., 2013,

Table 2. Comparison of the width of common diatom taxa in the 4 river types of central Portugal (Northern Mountain Streams - M; Littoral Rivers - L; Small Northern Rivers - N1 $\leq 100 \mathrm{~km}^{2}$; Medium-Large Northern Rivers - N1 $>100 \mathrm{~km}^{2}$ ) that showed at least one significant difference. Pseudo-f values for PERMANOVA pairwise tests results in which $0.05 \geq p \geq 0.01$ are represented with $*$ and results in which $p \leq 0.01$ are represented with **. Analysis in which variances are not homogeneous are represented with a Comparação da largura dos taxa de diatomáceas comuns em mais que 1 tipo de rio da região centro de Portugal (rios Montanhosos do Norte - M; Rios do Litoral Centro - L; Rios do Norte de Pequena Dimensão - N1 $\leq 100 \mathrm{~km}^{2}$; Rios do Norte de Média Grande Dimensão $N 1>100 \mathrm{~km}^{2}$ ) que demonstraram pelo menos uma diferença significativa. Valores pseudo-F dos testes PERMANOVA nos quais $0.05 \geq \mathrm{p} \geq 0.01$ estão representados com * e os resultados nos quais $\mathrm{p} \leq 0.01$ estão representados com **. As análises em que as variâncias não são homogéneas estão representadas com ${ }^{a}$.

\begin{tabular}{|c|c|c|c|c|c|c|}
\hline Species & $\mathbf{L} \neq \mathbf{M}$ & $\mathrm{L} \neq \mathrm{N} 1 \leq 100 \mathrm{~km}^{2}$ & $\mathrm{~L} \neq \mathrm{N} 1>100 \mathrm{~km}^{2}$ & $\mathrm{M} \neq \mathrm{N} 1 \leq 100 \mathrm{~km}^{2}$ & $\mathrm{M} \neq \mathrm{N} 1>100 \mathrm{~km}^{2}$ & $\mathrm{~N} 1 \leq 100 \mathrm{~km}^{2} \not \mathrm{N} 1>100 \mathrm{~km}^{2}$ \\
\hline $\begin{array}{l}\text { Achnanthidium } \\
\text { minutissimum }\end{array}$ & 0.93 & 1.13 & $2.45^{*}$ & 0.13 & $2.68 * *$ & $3.23 * *$ \\
\hline $\begin{array}{l}\text { Achnanthidium } \\
\text { rivulare }\end{array}$ & & 1.72 & 0.96 & & & $2.78 *$ \\
\hline $\begin{array}{l}\text { Cocconeis } \\
\text { pediculus }\end{array}$ & & $2.87 *$ & & & & \\
\hline Diatoma mesodon & & & & 0.77 & $3.71 *$ & $2.32 *$ \\
\hline Eolimna minima & $3 * *$ & 1.59 & 0.78 & $4.24 * *$ & $3.54 * *$ & 0.58 \\
\hline $\begin{array}{l}\text { Fistulifera } \\
\text { saprophila }\end{array}$ & & $6.80 * *$ & & & & \\
\hline $\begin{array}{l}\text { Gomphonema } \\
\text { parvulum }\end{array}$ & $3.98 * *$ & $3.47 * *$ & $0.89 * *$ & 0.13 & $6.19 * *$ & $5.65 * *$ \\
\hline $\begin{array}{l}\text { Gomphonema } \\
\text { rhombicum }\end{array}$ & & & & $4.1224 * *$ & 11.609 & $4.9984 * *$ \\
\hline $\begin{array}{l}\text { Karayevia } \\
\text { oblongella }\end{array}$ & $3.82 * *$ & $3.45 \mathrm{E}-02$ & 0.83 & 1.14 & $6.36^{* *}$ & 0.28 \\
\hline $\begin{array}{l}\text { Navicula } \\
\text { cryptocephala }\end{array}$ & & & & $3.48 * *$ & & \\
\hline $\begin{array}{l}\text { Navicula } \\
\text { cryptotenella }^{a}\end{array}$ & & & & $9.27 * *$ & & \\
\hline $\begin{array}{l}\text { Navicula } \\
\text { cryptotenelloides }\end{array}$ & & & $21.6 * *$ & & & \\
\hline $\begin{array}{l}\text { Nitzschia } \\
\text { inconspicua }\end{array}$ & & $3.50 * *$ & & & & \\
\hline $\begin{array}{l}\text { Nitzschia palea } \\
\text { var. debilis }\end{array}$ & & $3.64 * *$ & & & & \\
\hline $\begin{array}{l}\text { Planothidium } \\
\text { frequentissimum }^{a}\end{array}$ & & 1.26 & $2.29 *$ & & & 1.51 \\
\hline Reimeria sinuata ${ }^{a}$ & & $5.53 * *$ & 0.42 & & & $3.17 * *$ \\
\hline $\begin{array}{l}\text { Surirella } \\
\text { brebissonii }\end{array}$ & & $4.58 * *$ & & & & \\
\hline $\begin{array}{l}\text { Sellaphora } \\
\text { seminulum }\end{array}$ & & $3.70 * *$ & 0.5 & & & $4.19 * *$ \\
\hline
\end{tabular}



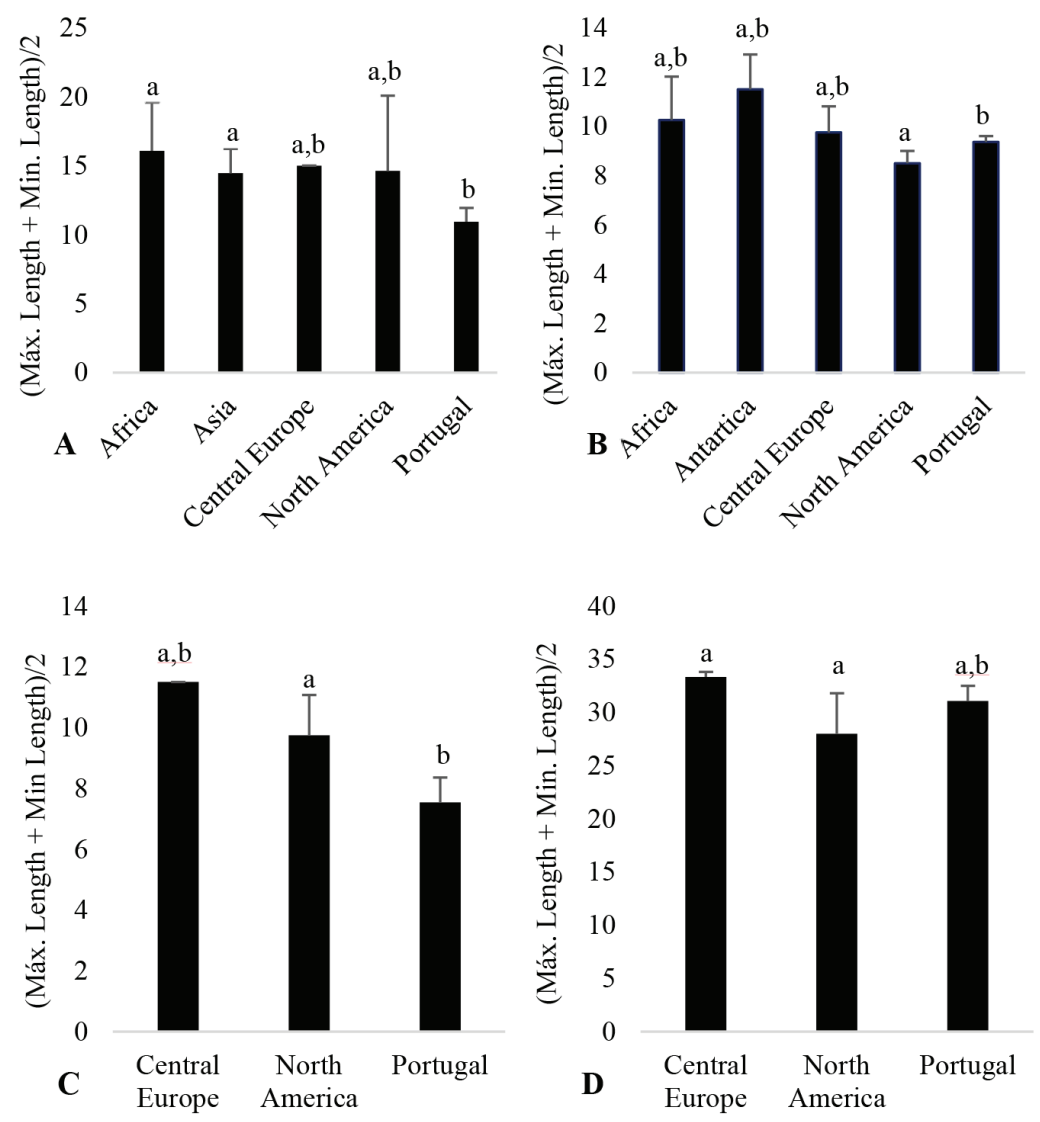

Figure 6. Comparison of the values (Maximum lengths + Minimum lengths)/2 of Achanthidium minutissimum (A), Achnanthidium subatomoides (B), Eolimna minima (C) and Eunotia incisa (D) around the world, different letters represent regions with significant differences in terms of diatom size $(p \leq 0.05)$. Comparação dos valores (Comprimento Máximo + Comprimento mínimo)/2 das espécies Achnanthidium minutissimum (A), Achnanthidium subatomoides (B), Eolimna minima $(C)$ e Eunotia incisa $(D)$ a nivel mundial; letras diferentes representam pares de regiões com diferenças significativas em termos de tamanho de cada espécie ( $\mathrm{p} \leq 0.05)$.

Stenger-Kovács et al., 2018), pH (Neustupa et al., 2013), oxygen and temperature (Walczýnka \& Sobczynk, 2017).

These differences may be explained by the fact that cell-size in diatoms can depend on some mechanisms not necessarily connected to what defines the concept of river type such as: their life cycle (Round et al., 1990; Mann et al., 1999). Diatoms can respond to the same condition by progressively reducing their cell size (asexual reproduction) or can restore their size by auxospore formation. Additionally, diatom cell size may respond to grazing (Tall et al., 2006) and other environmental conditions such as salinity (Stenger-Kovács et al., 2018) and anthropogenic pressure (Lange et al., 2016). Thus, the differ- ences observed and the absence of particular patterns may reflect variations not covered in this study. Studies made in controlled laboratory conditions should also contribute to clarify the observed patterns.

At the global spatial scale several differences between regions were registered, including within Europe. As most diatomists, we usually resort to diatom floras which are from other geographical regions. For example, in Portugal (SW Europe) we mostly use diatom floras from Central and Northern Europe. Nevertheless, we found size differences between the diatoms measured by us in Central Portugal and the range of sizes registered in other regions of Europe. In spite of these results, the number of works (publi- 
cations, floras, on-line databases) found for each species were not many. Therefore, care must be taken with these conclusions and further research should be undertaken based on measurements of diatoms from different areas where the study is taking place to confirm the observed patterns.

Our results indicate that in the potential development of an indirect functional approach for the assessment of rivers based on traits, as those that have been considered for other biological elements such as invertebrates (e.g. Statzner et al., 2005; Statzner \& Bêche, 2010; Feio \& Dolédec, 2012) or more recently for diatoms (e.g. Lavoie et al., 2006; Berthon et al., 2011; Talpoczai et al., 2017; Pandey et al., 2018; Stenger-Kovács et al., 2018), care must be taken

Table 3. Comparison of the $1 / \mathrm{w}$ ratio of common diatom taxa in the 4 river types of central Portugal (Northern Mountain Streams M; Littoral Rivers - L; Small Northern Rivers - N1 $\leq 100 \mathrm{~km}^{2}$; Medium-Large Northern Rivers - N1 $>100 \mathrm{~km}^{2}$ ) that showed at least one significant difference. Pseudo-F values for PERMANOVA pairwise tests results' in which $0.05 \geq p \geq 0.01$ are represented with * and results in which $p \leq 0.01$ are represented with **. Analysis in which variances are not homogeneous are represented with a Comparação do rácio c/l dos taxa de diatomáceas comuns em mais que 1 tipo de rio da região centro de Portugal (rios Montanhosos do Norte - M; Rios do Litoral Centro - L; Rios do Norte de Pequena Dimensão - N1 $\leq 100 \mathrm{~km}^{2}$; Rios do Norte de Média Grande Dimensão - N1 >100 km²) que demonstraram pelo menos uma diferença significativa. Valores pseudo-F dos testes PERMANOVA nos quais $0.05 \geq \mathrm{p} \geq 0.01$ estão representados com * e os resultados nos quais $\mathrm{p} \leq 0.01$ estão representados com **. As análises em que as variâncias não são homogéneas estão representadas com ${ }^{a}$.

\begin{tabular}{|c|c|c|c|c|c|c|}
\hline Species & $\mathbf{L} \neq \mathbf{M}$ & $\mathrm{L} \neq \mathrm{N} 1 \leq 100 \mathrm{~km} 2$ & $\mathrm{~L} \neq \mathrm{N} 1>100 \mathrm{~km} 2$ & $\mathrm{M} \neq \mathrm{N} 1 \leq 100 \mathrm{~km} 2$ & $\mathrm{M} \neq \mathrm{N} 1>100 \mathrm{~km} 2$ & $\mathrm{~N} 1 \leq 100 \mathrm{~km} 2 \neq \mathrm{N} 1>100 \mathrm{~km} 2$ \\
\hline $\begin{array}{l}\text { Achnanthidium } \\
\text { minutissimum }\end{array}$ & $2.53 *$ & 0.12 & 1.33 & $2.34 *$ & $3.35 * *$ & 1.1 \\
\hline $\begin{array}{l}\text { Achnanthidium } \\
\text { rivulare }\end{array}$ & & $2.86^{* *}$ & 1.33 & & & 1.58 \\
\hline $\begin{array}{l}\text { Achnanthidium } \\
\text { straubianum }^{a}\end{array}$ & & 0.18 & $4.66 * *$ & & & $6.69 * *$ \\
\hline $\begin{array}{l}\text { Achnanthidium } \\
\text { subtomoides }\end{array}$ & $1.78 *$ & 1.63 & 0.36 & 0.33 & $2.17 *$ & $2.51 *$ \\
\hline Amphora inariensis & & $4.22 * *$ & & & & \\
\hline Amphora pediculus ${ }^{a}$ & & $2.55^{*}$ & & & & \\
\hline Cocconeis euglypta & 1.16 & 0.98 & & $2.32 *$ & & \\
\hline Cocconeis pediculus & & $4.19 * *$ & & & & \\
\hline $\begin{array}{l}\text { Cocconeis placentula } \\
\text { var. lineata }^{a}\end{array}$ & & $2.73 * *$ & $4.61 * *$ & & & $3.39 * *$ \\
\hline Fragilaria parva & & & $3.42 * *$ & & & \\
\hline $\begin{array}{l}\text { Fistulifera } \\
\text { saprophila }\end{array}$ & & $6.82 * *$ & & & & \\
\hline $\begin{array}{l}\text { Gomphonema } \\
\text { parvulum }\end{array}$ & $2.04 *$ & 0.12 & $2.70 * *$ & $2.53 *$ & $5.24 *$ & $3.33 * *$ \\
\hline $\begin{array}{l}\text { Gomphonema } \\
\text { rhombicum }\end{array}$ & & & & 0.02501 & $5.3645 * *$ & $3.392 * *$ \\
\hline Mayammaea permitis & & $1.98 *$ & 1.05 & & & $2.60 *$ \\
\hline \multicolumn{7}{|l|}{$\begin{array}{l}\text { Navicula } \\
\text { cryptotenelloides }\end{array}$} \\
\hline Nitzschia dissipata & & $1.89 *$ & $4.91 * *$ & & & 1.73 \\
\hline $\begin{array}{l}\text { Planothidium } \\
\text { frequentissimum }\end{array}$ & & 0.55 & 1.24 & & & $2.01 *$ \\
\hline Reimeria sinuata & & $3.59 * *$ & 1.29 & & & 1.64 \\
\hline
\end{tabular}


in the establishment of reference values for metrics that contemplate diatom size.

We also recommend that measurements of diatoms are performed in ecological studies when size is a relevant feature, as the use of databases based on data from a given region may result in biased conclusions as variations in size occur at both regional and global scales.

\section{ACKNOWLEDGEMENTS}

This study was made possible by financial support from the FOUNDATION FOR SCIENCE AND TECHNOLOGY (Portugal) through the strategic project UID/MAR/04292/ 2019 granted to MARE, and UID/GEO/04035/ 2019 granted to GeoBioTec. We thank IMARCMA, Department of Life Sciences, University of Coimbra and the Biology Department, University of Aveiro for logistic support.

\section{REFERENCES}

ACCUWEATHER. 2018. Portugal - Metereologia: AccuWeather.com (PT-PT). https:/www. accuweather.com/pt/pt/portugal-weather

ADAMS, G. L., D. E., PICHLER, E. J. COX, E. J. OGORMAN, A. SEENEY, G. WOODWARD \& D. C. REUMAN. 2013. Diatoms can be an important exception to temperature-size rules at species and community levels of organization. Global Change Biology, 19: 3540-3552. DOI: 10.1111/gcb.12285

AFNOR. 2000. Qualite de l'Eau. Determination de l'indice biologique diatomees (IBD). Norme NF T90 354.

ALGARTE, V.M., L. RODRIGUES, V.L LANDEIRO, T. SIQUEIRA \& M. L. BINI. 2014. Variance partitioning of deconstructed periphyton communities: does the use of ecological traits matter? Hydrobiologia, 722: 279-290. DOI: 10.1007/s10750-013-1711-6

AMATO, A., L. ORSINI, D. DALELIO \& M. MONTRESOR. 2005. Life Cycle, Size Reduction Patterns, And Ultrastructure Of The Pennate Planktonic Diatom Pseudo-Nitzschia Delicatissima (Bacillariophyceae). Journal of Phycology, 41(3): 542-556. DOI: $10.1111 / \mathrm{j} .1529-8817.2005 .00080 . \mathrm{x}$
ANDERSON, M., R. GORLEY \& R. CLARKE. 2008. Permanova+ for Primer: Guide to Software and Statistical Methods. PRIMER-E, Plymouth Marine Laboratory, United Kingdom.

ATKINSON, D. 1994. Temperature and organism size - a biological law for ectotherms. Advanced Ecological Research, 25: 1-58.

BERTHON, V., A. BOUCHEZ \& F. RIMET. 2011. Using diatom lifeforms and ecological guilds to assess organic pollution and trophic level in rivers: a case study of rivers in southeastern France. Hydrobiologia, 673: 259-271. DOI: $10.1007 / \mathrm{s} 10750-011-0786-1$

BERVEN, K. A. 1982. The genetic basis of altitudinal variation in the wood frog Rana sylvati$c a$. I. An experimental analysis of life history traits. Evolution, 36(5): 962-983. DOI: 10.1111/j.1558-5646.1982.tb05466.x

BIZER, J. R. 1978. Growth rates and size at metamorphosis of high elevation populations of Ambystoma tigrinum. Oecologia, 34(2): 175-184.

BLACKBURN, T. M. \& B. A. HAWKINS. 2004. Bergmann's rule and the mammal fauna of northern North America. Ecography, 27: 715-724. DOI: 10.1111/j.0906-7590.2004. 03999.x

BOYCE, M. S. 1978. Climatic variability and body size variation in muskrats (Ondatra zibethicus) of North America. Oecologia, 36: 1-19. DOI: 10.1007/BF00344567

BRADY, L. D. \& R. A. GRIFFITHS. 2000. Developmental responses to pond desiccation in tadpoles of the British anuran amphibians (Bufo bufo, B. calamita and Rana temporaria). Journal of Zoology, 252: 61-69. DOI: 10.1017/s0952836900009079

BREHM, G., D. ZEUSS, \& R. K. COLWELL. 2018. Moth body size increases with elevation along a complete tropical elevational gradient for two hyperdiverse clades. Ecography, 42(4): 632-642. DOI: 10.1111/ecog.03917

CARRICK, H. J. \& R. L. LOWE. 1989. Benthic algal response to $\mathrm{N}$ and $\mathrm{P}$ enrichment along a pH gradient. Hydrobiologia, 179: 119-127.

CLARKE, K. R. \& R. N. GORLEY. 2006. PRIMER V6: User Manual/Tutorial. PRIMER-E Ltd. Plymouth Marine Laboratory, 
United Kingdom.

COESEL, P. F. M. 1982. Structural characteristics and adaptations of desmid communities. Journal of Ecology, 70(1): 163-177. DOI: $10.2307 / 2259871$

DAUFRESNE, M., K. LENGFELLNER \& U. SOMMER. 2009. Global warming benefits the small in aquatic ecosystems. Proceedings of the National Academy of Science USA, 106 (31): 12788-12793. DOI: 10.1073/pnas. 0902080106

DENVER, R. J., N. MIRHADI \& M. PHILLIPS. 1998. Adaptive plasticity in amphibian metamorphosis: Response of Scaphiopus hammondii tadpoles to habitat desiccation. Ecology, 79(6): 1859-1872. DOI: 10.2307/176694

DESAI, A. S. \& R. K. SINGH. 2009. The effects of water temperature and ration size on growth and body composition of fry of common carp, Cyprinus carpio. Journal of thermal Biology, 34(6): 276-280. DOI: 10.1016/j.jtherbio.2009.03.005

DUONG, T., A. FEURTET-MAZEL, M. COSTE, D. K. DANG \& A. BOUDOU. 2007. Dynamics of diatom colonization process in some rivers influenced by urban pollution (Hanoi, Vietnam). Ecological Indicators, 7(4): 839-851. DOI: 10.1016/j.ecolind.2006.10.003

ELIAS, C. L., A. R. CALAPEZ, S. F. P. ALMEIDA \& M. J. FEIO. 2015. From perennial to temporary streams: an extreme drought as a driving force of freshwater communities' trait. Marine Freshwater Research. 66(5): 1-12. DOI: $10.1071 / \mathrm{mf} 13312$

EUROPEAN COMISSION. 2000. Directive 2000/60/EC of the European Parliament and of the Council establishing a framework for the Community action in the field of water policy. Official Journal of the European Communities, L327: 1-73.

EUROPEAN COMMITTEE OF STANDARDIZATION. 2003. European Standard. EN 13946. Water quality - Guidance Standard for the routine sampling and pre-treatment of benthic diatoms from rivers. CEN, Brussels.

EUROPEAN COMMITTEE OF STANDARDIZATION. 2004. European Standard. EN 14407. Water Quality - Guidance standard for the identification, enumeration and interpre- tation of benthic diatoms samples from running waters. CEN, Brussels.

EUROPEAN COMMITTEE OF STANDARDIZATION. 2006. European Standard. EN 14996. Water quality - Guidance on assuring the quality of biological ad ecological assessments in aquatic environment. CEN, Brussels. FEIO, M. J. \& P. PINTO. 2009. Tipologia e cenários biológicos do elemento macroinvertebrados para Portugal Continental. Recursos Hidricos, 30:19-27.

FEIO, M. J., S. F. P. ALMEIDA, S. C. CRAVEIRO \& A. J. CALADO. 2007. Diatoms and macroinvertebrates provides consistent and complementary information on environmental quality. Fundaments of Applied Limnology, l'Archive für Hydrobiologie, 169(3): 247- 258. DOI: $10.1127 / 1863-9135 / 2007 / 0169-0247$

FEIO, M. J., S. F. P. ALMEIDA, S. C. CRAVEIRO \& A. J. CALADO. 2009. A comparison between biotic indices and predictive models in stream water quality assessment based on benthic diatom communities. Ecological Indicators, 9(3): 497-507. DOI: 10.1016/j. ecolind.2008.07.001

FEIO, M. J. \& S. DOLÉDEC. 2012. Integration of invertebrate traits into predictive models for indirect assessment of stream functional integrity: a case study in Portugal. Ecological Indicators, 15(1): 236-247. DOI: 10.1016/j. ecolind.2011.09.039

HOVENDEN, M. J., K. E. WILLS, R. E. CHAPLIN, J. K. SCHOOR, A. L. WILLIAMS, Y. OSANAI, \& P. C. NEWTON. 2008. Warming and elevated $\mathrm{CO} 2$ affect the relationship between seed mass, germinability and seedling growth in Austrodanthonia caespitosa, a dominant Australian grass. Global Change Biology, 14(7): 1633-1641. DOI: 10.1111/j. 1365-2486.2008.01597.x

INAG, I.P. 2008a. Tipologia de Rios em Portugal Continental no âmbito da implementação da Diretiva Quadro da Água: I-Caracterização abiótica. Ministério do Ambiente, do Ordenamento do Território e do Desenvolvimento Regional. Instituto da Água, I.P.

INAG, I.P. 2008b. Protocolo de amostragem e análise para o fitobentos-diatomáceas em Manual para a Avaliação Biológica da Quali- 
dade da Água em Sistemas Fluviais Segundo a Diretiva do Quadro da Água. Instituto da Água, I.P.

IRIE, T. \& K. FISCHER. 2009. Ectotherms with a calcareous exoskeleton follow the temperature-size rule-evidence from field survey. Marine Ecology Progress Series, 385: 33-37. DOI: 10.3354/meps08090

KIM, S., D. GITZ, R. SICHER, J. BAKER, D. TIMLIN \& V. REDDY. 2007. Temperature dependence of growth, development, and photosynthesis in maize under elevated $\mathrm{CO}_{2}$. Environmental and Experimental Botany, 61(3): 224-236. DOI: $10.1016 /$ j.envexpbot. 2007.06.005

KRAMMER, K. \& H. LANGE-BERTALOT. 1986. 'Su"ßwasserflora von Mitteleuropa. Bd 2/1. Bacillariophyceae. 1. Teil: Naviculaceae. Gustav Fisher Verlag: Stuttgart, Germany.

KRAMMER, K. \& H. LANGE-BERTALOT. 1988. 'Su“ßwasserflora von Mitteleuropa. Bd 2/2. Bacillariophyceae. 2. Teil: Bacillariaceae, Epithemiaceae, Surirellaceae. Gustav FisherVerlag: Stuttgart, Germany.

KRAMMER, K. \& H. LANGE-BERTALOT. 1991a. 'Su"ßwasserflora von Mitteleuropa. Bd 2/3. Bacillariophyceae. 3. Teil: Centrales, Fragilariaceae, Eunotiaceae. Gustav Fisher Verlag: Stuttgart, Germany.

KRAMMER, K. \& H. LANGE-BERTALOT. 1991b. 'Su“ßwasserflora von Mitteleuropa. Bd 2/4. Bacillariophyceae. 4. Teil: Achnanthaceae Kritische Erga"nzungen zu Navicula (Lineolatae) und Gomphonema. Gustav Fisher Verlag: Stuttgart, Germany.

KRAMMER, K. 1997. Die cymbelloiden Diatomeen. Eine Monographie der weltweit bekannten Taxa. Teil 1. Allgemeines und Encyonema. Bibliotheca Diatomologica 36.

KRAMMER, K. 2000. 'Diatoms of Europe: Diatoms of the European Inland Waters and Comparable Habitats. Vol. 1. The genus Pinnularia. A.R.G. Gantner-Verlag K.G, Ruggell, Liechtenstein.

KRAMMER, K. 2001. 'Diatoms of Europe: Diatoms of the European Inland Waters and Comparable Habitats. Vol. 2. Navicula sensu stricto. 10 Genera separated from Navicula sensu lato Frustulia. A.R.G. Gantner-Verlag
K.G. Ruggell, Liechtenstein.

KRAMMER, K. 2002. 'Diatoms of Europe: Diatoms of the European Inland Waters and Comparable Habitats. Vol. 3. The genus Cymbella. A.R.G. Gantner-Verlag K.G. Ruggell, Liechtenstein.

KRAMMER, K. 2009. 'Diatoms of Europe: Diatoms of the European Inland Waters and Comparable Habitats. Vol. 5. Amphora sensu lato. A.R.G. Gantner-Verlag K.G.: Ruggell, Liechtenstein.

LANGE, K., C. R. TOWNSEND \& C. D. MATTHAEI. 2016. A trait-based framework for stream algal communities. Ecology and Evolution, 6(1): 23-36. DOI: 10.1002/ece3.1822

LAVOIE, I., S., CAMPEAU, M. A. FALLU \& P. J. DILLON. 2006. Diatoms and biomonitoring: should cell size be accounted for? Hydrobiologia, 573(1): 1-16. DOI: 10.1007/s10750006-0223-z

LAVOIE, I.. J. LENTO \& A. MORIN. 2010. Inadequacy of size distributions of stream benthic diatoms for environmental monitoring. Journal of the North American Benthological Society, 29 (2): 586-601. DOI: 10.1899/09-062.1

LEDESMA, N. A., M. NAKATA \& N. SUGIYAMA. 2008. Effect of high temperature stress on the reproductive growth of strawberry cvs. 'Nyoho' and 'Toyonoka'. Sciemtia Horticulturae, 116: 186-193. DOI: 10.1016/j. scienta.2007.12.010

LEWANDOWSKA A. M. \& U. SOMMER. 2010. Climate change and the spring bloom: a mesocosm study on the influence of light and temperature on phytoplankton and mesozooplankton. Marine Ecology Progress Series, 405: 101-111. DOI: 10.3354/meps08520

LI, W. K., F. A. MCLAUGHLIN, C. LOVEJOY \& E. C. CARMACK. 2009. Smallest Algae Thrive As the Arctic Ocean Freshens. Science, 326(5952): 539-539. DOI: 10.1126/ science. 1179798

LITCHMAN, E., C. A. KLAUSMEIER, J. R. MILLER, O. M. SCHOFIELD, P. G. FALKOWSKI. 2006. Multi-nutrient, multi-group model of present and future oceanic phytoplankton communities. Biogeosciences Discussions, 3(3): 607-663. DOI: 
10.5194/bgd-3-607-2006

LUIS, A., P. TEIXEIRA, S. F. P., ALMEIDA, J. X. MATOS, E. F. SILVA. 2011. Environmental impact of mining activities in the Lousal area (Portugal): Chemical and diatom characterization of metal-contaminated stream sediments and surface water of Corona stream. Science of the Total Environment, 409: 4312-4325. DOI: 10.1016/j.scitotenv. 2011.06 .052

MANN, D.G., V. A. CHEPURNOV \& S. J. M. DROOP. 1999. Sexuality, incompatibility, size variation, and preferential polyandry in natural populations and clones of Sellaphora pupula (Bacillariophyceae). Journal of Phycology, 35: 152-170. DOI: 10.1046/j.15298817.1999.3510152.x

MORAN, X. A. G., A. LOPEZ-URRUTIA, A. CALVO-DIAZ \& W. K. W. LI W.K.W. 2010. Increasing importance of small phytoplankton in a warmer ocean. Global Change Biology, 16 (3): 1137-1144. DOI: 10.1111/j.1365-2486. 2009.01960.x

MORIN, A., N. BOURASSA \& A. CATTANEO. 2001. Use of size spectra and empirical models to evaluate trophic relationships in streams. Limnology and Oceanography, 46(4): 935-940. DOI: 10.4319/1o.2001.46.4.0935

NEUSTUPA, J., J. VASELÁ \& S. JAN. 2013. Differential cell size structure of desmids and diatoms in phytobenthos of peatlands. Hydrobiologia, 709(1): 159-171. DOI: 10.1007/ s10750-013-1446-4

PANDEY, L. K., I. LAVOIE, S. MORIN, J. PARK, J. LYU, S. CHOI, H. LEE \& T. HAN. 2018. River water quality assessment based on a multi-descriptor approach including chemistry, diatom assemblage structure, and non-taxonomical diatom metrics. Ecological Indicators, 84: 140-151. DOI: $10.1016 / \mathrm{j}$. ecolind.2017.07.04

PRYGIEL, J., B. A. WHITON \& J. BUROWSKA (eds.) 1999. Use of algae for monitoring rivers III. Agence de l'Eau Artois Picardie, Douai, France,

RAMIREZ, L., J. A. F. DINIZ \& B. A. HAWKINS. 2008. Partitioning phylogenetic and adaptive components of the geographical body-size pattern of new world birds. Global
Ecology and Geography, 17: 100-110. DOI: 10.1111/j.1466-8238.2007.00346.x

RAVEN P. J., N. T. H. HOLMES, P. CHARRIER, F. H. DAWSON, M. NAURA, P. J. BOON. 2002. Towards a Harmonized Assessment of Rivers in Europe: a Qualitative Comparison of Three Survey Methods. Aquatic Conservation: Marine and Freshwater Ecosystems, 12: 405-424

REY, P., J. C. TAYLOR, A. LAAS, L. VAN RENSBURG \& A. VOSLOO. 2004: Determining the possible application value of diatoms as indicators of general water quality: A comparison with SASS 5. Water SA, 30(3): 325 - 332. DOI: 10.4314/wsa.v30i3.5080

REYNOLDS, C. S. 2006. Ecology of Phytoplankton. Cambridge University Press, New York, USA.

RIMET, F. \&. A. BOUCHEZ. 2012. Life-forms, cell-sizes and ecological guilds of diatoms in European Rivers. Management of Aquatic Systems, 406 (1): 3-12. DOI: 10.1051/kmae/ 2012018

ROBERSTON, F. W. 1959. Studies on quantitative inheritance. XII. Cell Size and number in relation to genetic and environmental variation of body size in Drosophila. A.R.C. Animal Genetics Unit, Institute of Animal Genetics, Edinburgh.

ROUND, F. E., R. M. CRAWFORD \& D. G. MANN. 1990. Diatoms: Biology and Morphology of the Genra. Cambridge University Press. Cambridge.

SAHIN, T. 2001. Effect of water temperature on growth of hatchery reared Black Sea turbot, Scophthalmus maximus (Linnaeus, 1758). Turkish. Journal of Zoology, 25(3): 183-186.

SCHÄUBLE, C. S. 2004. Variation in body size and sexual dimorphism across geographical and environmental space in the frogs Lymnodinastes tasmaniensis \& L. peronii. Biological Journal of the Linnean Society, 82: 39-56. DOI: $10.1111 /$ j.1095-8312.2004.00315.x

SHERIDAN, J. A. \& D. Bickford. 2011. Shrinking body size as ecological response toclimate change. Nature Climate Change, 1: 401-406.

STATZNER, B. \& L. A. BÊCHE. 2010. Can biological invertebrate traits resolve effects of multiple stressors on running water ecosys- 
tems? Freshwater Biology, 55: 80-119. DOI: 10.1111/j.1365-2427.2009.02369.x

STATZNER, B., P. BADY, S. DOLÉDEC, \& F. SCHÖLL. (2005). Invertebrate traits for the biomonitoring of large European rivers: An initial assessment of trait patterns in least impacted river reaches. Freshwater Biology, 50 (12): 2136-2161. DOI: 10.1111/j.13652427.2005.01447.x

STATZNER, B., B. BIS,S. DOLÉDEC \& P. USSEGLIO-POLATERA. 2001a. Perspectives for biomonitoring at large spatial scales: a unified measure for the functional composition of invertebrate communities in European running waters. Basic Applied Ecology, 2(1): 73-85. DOI: 10.1078/1439-1791-00039

STATZNER, B., A. G. HILDREW \& V. H. RESH. 2001b. Species traits and environmental constraints: entomological research and history of ecological theory. Annual Revision of Entomology, 46: 291-316. DOI: 10.1146/ annurev.ento.46.1.291

STENGER-KOVÁCS, C., K. KÖRMENDI, E. LENGYEL, A. ABONYI, É HAJNAL, B. SZABÓ, K. BUCZKÓ \& J. PADISÁK. 2018. Expanding the trait-based concept of benthic diatoms: Development of trait and species-based indices for conductivity as the master variable of ecological status in continental saline lakes. Ecological Indicators, 95: 63-74. DOI: 10.1016/j.ecolind.2018.07.026

STILLWELL, R. C. \& C. W. FOX. 2009. Geographic variation in body size, sexual size dimorphism and fitness components of a seed beetle: local adaptation versus phenotypic plasticity. Oikos, 118(5): 703-712. DOI: 10.1111/j.1600-0706.2008.17327.x

TALL, L., L. CLOUTIER \& A. CATTANEO. 2006. Grazer-diatom size relationships in an epiphytic community. Limnology and Oceanography, 51: 1211-1216. DOI: 10.4319/1o. 2006.51.2.1211

TALPOCZAI, K., A. BOUCHEZ, A. STRENGER-KOVÀCS, J. PADISÀK \& F. RIMET. 2016. Trait-based ecological identifications for benthic algae: review and perspectives. Hydrobiologia, 776(1): 1-17. DOI: 10.1007/s10750-016-2736-4

TAPOLCZAI, K., A. BOUCHEZ, C.
STENGER-KOVÁCS, J. PADISÁK \& F. RIMET. 2017. Taxonomy- or trait based ecological assessment for tropical rivers? Case study on benthic diatoms in Mayotte island (France, Indian Ocean). Science of The Total Environment, 607-608: 1293-1303. DOI: 10.1016/j.scitotenv.2017.07.093

TISON, J., Y. S. PARK, M. COSTE, J. G. WASSON, F. RIMET, L. ECTOR \& F. DELMAS. 2007. Predicting diatom reference communities at the French hydrosystem scale: A first step towards the definition of the good ecological status. Ecological Modelling, 203 (1-2): 99-108. DOI: 10.1016/j.ecolmodel. 2006.02.047

TORNÈS, E., J. CAMBRA, J. GOMÀ, R. ORTIZ \& S. SABATER. 2007. Indicator taxa of benthic diatom communities: a case study in Mediterranean streams. Annales Limnologie International Journal of Limnology, 43(1): 1-11. DOI: 10.1051/limn/2007023

WALCZÝNSKA, A. \& L. SOBCZYNK. 2017. The underestimated role of temperature-oxygen relationship in large-scale studies on size-to-temperature response. Ecology and Evolution, 7: 7434-7441. DOI: 10.1002/ece3. 3263

WHITTON, B.A. \& E. ROTT, (eds.) 1996. Use of algae for monitoring rivers III. Institut für Botanik. University Innsbrug, Insbrug.

WILLIAMSON, C. E., G. GRAD, H. J. DE LANGE, S. GILROY \& D. M. KARAPELOU. 2002. Temperature-dependent ultraviolet responses in zooplankton: Implications of climate change. Limnology and Oceonography, 47: 1844-1848. DOI: 10.4319/lo.2002. 47.6.1844

WIMPENNY, R. 1936. The Size of Diatoms. I. The Diameter Variation of Rhizosolenia Styliformis Brightw. and R. Alata Brightw. in Particular and of Pelagic Marine Diatoms in General. Journal of the Marine Biological Association of the United Kingdom, 21(1): 29-60.DOI: 10.1017/S0025315400011188

WINDER, M. \& U. SOMMER. 2012. Phytoplankton response to a changing climate. Hydrobiologia, 698: 5-16. DOI: 10.1007/97894-007-5790-5 2

WINDER, M.., J. E. REUTER \& S. G. 
SCHLADOW. 2009. Lake warming favours small-sized planktonic diatom species. Proceedings of the Royal Society B: Biological Sciences, 276: 427-435. DOI: 10.1098/ rspb.2008.1200
ZHONG, M., X. YU \& W. LIAO. 2018. A Review for Life-history Traits Variation in Frogs Especially for Anurans in China. Asian Herpetological Research, 9 (3): 165-174. DOI: 10.16373/j.cnki.ahr.180052 